\title{
Oxidative/antioxidative enzyme-mediated antiproliferative and proapoptotic effects of the GPER1 agonist G-1 on lung cancer cells
}

\author{
AKIF HAKAN KURT ${ }^{1}$, AHMET ÇELIK ${ }^{2}$ and BEKIR MEHMET KELLECI ${ }^{3}$ \\ Departments of ${ }^{1}$ Pharmacology and ${ }^{2}$ Biochemistry, Faculty of Medicine; ${ }^{3}$ Department of Biology, \\ Faculty of Science and Art, Kahramanmaras Sutcu Imam University, Kahramanmaras, Turkey
}

Received October 11, 2014; Accepted August 6, 2015

DOI: 10.3892/ol.2015.3711

\begin{abstract}
Estrogen mediates fast signal responses or transcriptional events via $\mathrm{G}$ protein-coupled estrogen receptor 1 (GPER1). However, there is no data on the effect of GPER1 on lung cancer cell proliferation and apoptosis. The present study aimed to analyze the anticancer effects of the GPER1 agonist G-1 on A549 human lung cancer cells. A549 cells were treated with 17/-estradiol and G-1, and cell proliferation was analyzed using MTT and WST assays. In addition, the apoptotic effects induced by G-1 were investigated using acridine orange/ethidium bromide staining. A549 cells were treated with a half maximal inhibitory concentration of G-1 for $72 \mathrm{~h}$, and nitric oxide (NO) levels and superoxide dismutase (SOD), catalase and glutathione peroxidase (GPx) enzyme activities were analyzed by spectrophotometry. The results revealed that G-1 significantly decreased cell proliferation. In addition to the antiproliferative effect of G-1, a marked increase in apoptotic activity was observed when cells were treated with $2 \times 10^{-5} \mathrm{M}$ G-1. Furthermore, G-1 increased NO levels, and SOD and GPx activity. These findings indicate that the GPER1 agonist G-1 is able to exert antiproliferative and proapoptotic effects on A549 cells, and that oxidant and antioxidant molecules may mediate these effects.
\end{abstract}

\section{Introduction}

Lung cancer is one of the most commonly occurring cancers and is associated with a high rate of mortality (1). The disease is responsible for $31 \%$ of cancer-associated mortalities in males and $25 \%$ of cancer-associated mortalities in females (2). Non-small-cell lung carcinoma (NSCLC) constitutes $>85 \%$ of all lung cancers (3). For early-stage NSCLC patients, surgery is the preferred treatment, while radiotherapy and/or

Correspondence to: Dr Akif Hakan Kurt, Department of Pharmacology, Faculty of Medicine, Kahramanmaras Sutcu Imam University, Emniyet Street, Kahramanmaras 46050, Turkey

E-mail: hkurt@ksu.edu.tr

Key words: A549 cells, G protein-coupled estrogen receptor 1, G-1, lung cancer, $17 \beta$-estradiol chemotherapy is preferred for late-stage patients or patients for whom surgery is not possible (2). The overall five-year survival rate of NSCLC patients is $<10 \%$ (4).

Studies of various neoplastic diseases, primarily breast and endometrial carcinoma, have demonstrated the prognostic significance of estrogen receptors (5). In addition, epidemiological studies have indicated that the incidence of lung cancer is lower in females compared with that of males of the same age (6). It has also been hypothesized that increased parity in females is associated with a decreased risk of lung cancer development, and that hormone replacement treatment suppresses lung cancer progression (7).

Estrogen predominantly binds to two receptors, estrogen receptors (ERs) $\alpha$ and $\beta$, and regulates a number of biological processes, including cell proliferation, differentiation, apoptosis, inflammation and metabolism (8). ER $\alpha$ and ER $\beta$ proteins have been shown to be expressed in primary lung tumors (9). Furthermore, these receptors are expressed in NSCLCs and have been demonstrated to mediate the transcriptional effects of estrogen (10). Until recently, only canonical ERs were considered to mediate the effect of estrogens. Following their activation, these canonical receptors are transported into the nucleus to produce genomic or non-genomic responses (11). However, the inhibition or knockdown of ER $\alpha$ and ER $\beta$ does not eliminate estrogen responses in various tissues (12). More recent studies have revealed that estrogen may mediate fast signal responses or transcriptional events via $\mathrm{G}$ protein-coupled estrogen receptor 1 (GPER1) (13). GPER1 is expressed in human brain, liver, heart, kidney, pancreatic, placental, blood vessel, bone, lymphoid, endometrial, ovarian, breast and lung cancer tissues (14). This receptor may be localized on the cell membrane, nucleus, endoplasmic reticulum, mitochondria or Golgi apparatus, and its effects vary depending on this specific intracellular localization (14). It has been suggested that G-1 (chemical name, 1-[4-(6-bromo-1,3-benzodioxol-5-yl)-3a,4,5,9b-tetrahydro-3H-cyclopenta[c]quinolin-8-yl]-ethanone) acts a specific GPER1 agonist (15). GPER1-dependent antiproliferative and proapoptotic effects of G-1 have been observed in prostate cancer (PC-3) and breast cancer (MCF-7) cells (16,17). However, GPER1-independent antiproliferative and proapoptotic effects of G-1 have been observed in ovarian cancer (KGN) and breast cancer (MDA-MB 231) cells (18).

Antioxidants have an essential role in cell protection against reactive oxygen species (19). The oxidation of 
antioxidant enzymes reduces the capacity of cells to eliminate free radicals (19). Therefore, an important approach in antitumor therapeutic strategies is to inhibit antioxidant systems, such catalase, superoxide dismutase (SOD) and glutathione peroxidase (GPx), which are the primary defense lines of the cell (19). A number of studies have shown the influence of estrogen and GPER1 on antioxidant enzymes and cytokine production $(20,21)$.

Previous studies have revealed that GPER1 expression is higher in various types of lung cancer tissues, including adenocarcinoma, squamous-cell carcinoma and giant-cell carcinoma, compared with normal lung tissue (22). Overexpression of GPER1 in lung cancer may reflect a defense mechanism against the hyperproliferation of cancer cells, with activation of this receptor leading to antiproliferative or proapoptotic effects (22). However, the antiproliferative or proapoptotic effects of GPER1 agonists in lung cancer cells have not yet been demonstrated. Therefore, the present study aimed to investigate the oxidant and antioxidant enzyme-mediated antiproliferative and apoptotic effects of the GPER1 agonist G-1 on lung cancer cells.

\section{Materials and methods}

Cell culture and chemicals. A549 human lung cancer cells were obtained from the American Type Cell Collection (Manassas, VA, USA). Cells were cultured in RPMI-1640 medium (Biochrom, Ltd., Cambridge, UK) supplemented with $10 \%$ fetal bovine serum (FBS; Gibco Life Technologies, Carlsbad, CA, USA) and $100 \mathrm{U} / \mathrm{ml}$ penicillin (Sigma-Aldrich, St. Louis, $\mathrm{MO}, \mathrm{USA}$ ) at $37^{\circ} \mathrm{C}$ in a humidified atmosphere of $5 \% \mathrm{CO}_{2}$. For 3 days prior to the experiment, A549 cells were cultured with phenol red-free RPMI-1640 containing 10\% dextran-coated charcoal-FBS (Gibco Life Technologies). The negative control condition for all assays was untreated medium containing vehicle [0.1\% dimethyl sulfoxide (DMSO)]. The DMSO and estrogen $17 \beta$-estradiol were purchased from Sigma-Aldrich, and G-1 and G-15 were purchased from Merck Millipore (Darmstadt, Germany).

MTT and WST-8 assay. A549 human lung cancer cells were treated with various concentrations $\left(10^{-8}, 10^{-7}, 10^{-6}, 10^{-5}\right.$ and $10^{-4} \mathrm{M}$ ) of $17 \beta$-estradiol and G-1 in 96-well plates and incubated for 48 or $72 \mathrm{~h}$. Following incubation, MTT solution (Sigma-Aldrich) was added to each well at a concentration of $0.5 \mathrm{mg} / \mathrm{ml}$, and incubated for $4 \mathrm{~h}$ at $37^{\circ} \mathrm{C}$. At the end of this period, $100 \mu 1$ DMSO solvent was added to each well. The absorbance values [optical density (OD)] at $570 \mathrm{~nm}$ of the solution in each well were read using a spectrophotometer (ELx800 Absorbance Reader; BioTek Instruments, Inc., Winooski, VT, USA). The antiproliferative potential of the G-1 was expressed as a half maximal inhibitory concentration $\left(\mathrm{IC}_{50}\right)$ value in $\mathrm{A} 549$ lung cancer cells; only the $\mathrm{IC}_{50}\left(2 \times 10^{-5} \mathrm{M}\right)$ was subsequently used in the present study. The cells $\left(5 \times 10^{4} /\right.$ well $)$ were treated with G-1 $\left(2 \times 10^{-5} \mathrm{M}\right)$, either alone or in combination with G-15 $\left(5 \times 10^{-5} \mathrm{M}\right)$, at $37^{\circ} \mathrm{C}$ in an atmosphere of $5 \% \mathrm{CO}_{2}$ for 48 and $72 \mathrm{~h}$. A WST-8 assay, Cell Counting Kit-8 (Sigma-Aldrich), was also used to assess cell proliferation, according to the manufacturer's instructions, and absorbance at $450 \mathrm{~nm}$ was measured using an ELx800 microplate reader.
Acridine orangelethidium bromide staining. Acridine orange/ethidium bromide staining was conducted to detect morphological evidence of apoptosis. A549 cells were treated with G-1 for $72 \mathrm{~h}$. The cells were washed with phosphate-buffered saline (PBS; Merck Millipore) and incubated for $5 \mathrm{~min}$ with a solution of $10 \mu \mathrm{l}$ of acridine orange/ethidium bromide (Sigma-Aldrich) made up to $100 \mu \mathrm{l}$ using PBS. The cells were then washed with PBS and six microscopic fields were examined under an Axio Vert.A1 inverted fluorescence microscope (Zeiss, Oberkochen, Germany). The percentage of apoptotic cells was calculated using the following formula: Apoptotic rate $(\%)=$ number of apoptotic cells / total number of cells counted (23).

Biochemical measurements. Cells at $70-80 \%$ confluence were washed twice with $\mathrm{PBS}(\mathrm{pH} 7.2)$ and treated with trypsin/EDTA (0.25/0.02\%; Merck Millipore) in PBS for $10 \mathrm{~min}$. The cell suspension was centrifuged for $10 \mathrm{~min}$ at $400 \mathrm{x}$ g. Cell pellets were then lysed in $50 \mathrm{mM}$ phosphate buffer solution (0.1 M, pH 7.0; Sigma-Aldrich), followed by sonication for $2 \mathrm{~min}$ on ice. The mixture was then centrifuged for $10 \mathrm{~min}$ at $14,000 \mathrm{x} \mathrm{g}$ and the supernatant was assayed for protein concentration and enzymatic activities.

Catalase (CAT) activity was determined as described by Aebi (24). Briefly, $100 \mu$ l supernatant was incubated with an equal volume of absolute alcohol for $30 \mathrm{~min}$ at $0^{\circ} \mathrm{C}$, followed by the addition of $100 \mu \mathrm{l}$ Triton X-100 (Sigma-Aldrich). A known volume of this mixture $(200 \mu \mathrm{l})$ was mixed with an equal volume of $0.066 \mathrm{M}$ hydrogen peroxidase $\left(\mathrm{H}_{2} \mathrm{O}_{2}\right)$ in phosphate buffer solution, and absorbance was measured at $240 \mathrm{~nm}$ for $30 \mathrm{sec}$ using a Shimatzu UV-1201 spectrophotometer (Shimadzu Corp., Kyoto, Japan). Protein levels were estimated as described by Lowry et al (25) and activity was expressed in units of GPx per mg protein.

SOD activity was determined as described by Fridovich (26). The principle of the method is based on the inhibition of nitro blue tetrazolium chloride (NBT) reduction by the xanthine-xanthine oxidase system, a superoxide generator. Xanthine (Sigma-Aldrich) and xanthine oxidase (Sigma-Aldrich) generate superoxide radicals, which react with NBT (Sigma-Aldrich) to form a red formazan dye. SOD activity was then determined according to the degree of inhibition of this reaction. One unit of SOD was defined as the quantity of enzyme $(\mathrm{mg})$ causing $50 \%$ inhibition in the NBT reduction rate. SOD activity was expressed as units of SOD per mg protein.

The GPx assay was based on the oxidation of nicotine adenosine dinucleotide phosphate (NADPH; Sigma-Aldrich) to $\mathrm{NADP}^{+}$, which is accompanied by a decrease in absorbance at $340 \mathrm{~nm}$. The rate of this decrease is directly proportional to the GPx activity in the sample (27). Therefore, GPx activity was measured by the enzymatic reaction that was initiated by adding $\mathrm{H}_{2} \mathrm{O}_{2}$ to a reaction mixture containing reduced glutathione, NADPH and glutathione reductase (Sigma-Aldrich). The change in the absorbance at $340 \mathrm{~nm}$ was monitored using a Shimatzu UV-1201 spectrophotometer (Shimadzu Corp.). Protein levels were estimated as described by Lowry et al (25) and activity was expressed in units of GPx per mg protein.

The determination of concentration levels of nitrite, which is the stable end product of nitric oxide (NO) radicals, was 
$\mathbf{A}$

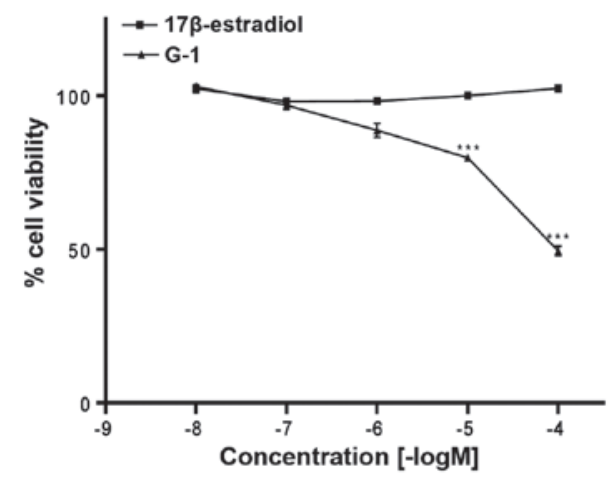

C

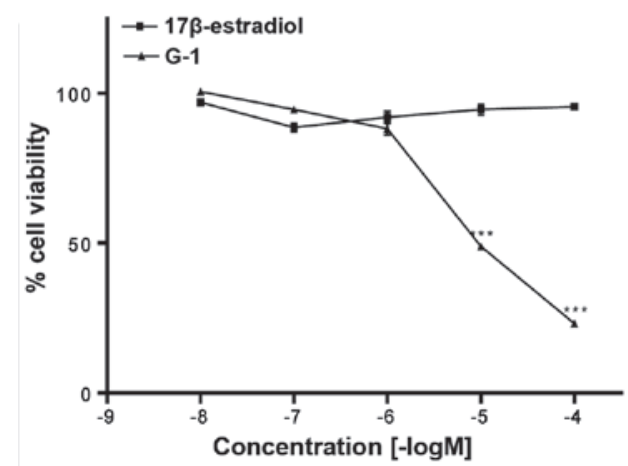

B WST- 848 hours

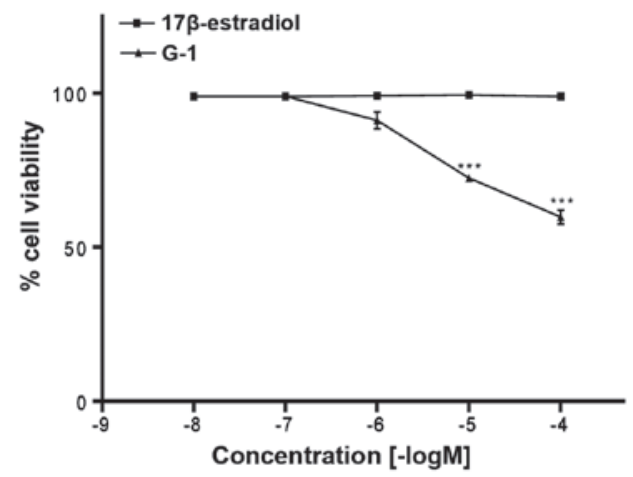

D

WST-8 72 hours

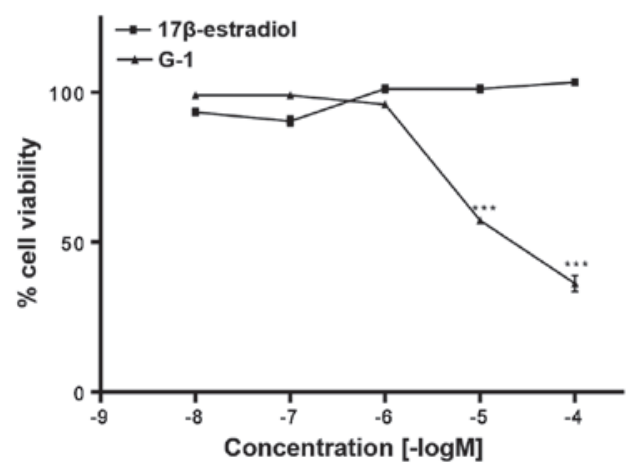

Figure 1. Concentration and time-dependent response curves for G-1 and 17ß-estradiol on A549 cells, assessed by MTT assay at (A) 48 and (B) 72 h, and by WST- 8 assay at (C) 48 and (D) $72 \mathrm{~h}$. The results are expressed as mean \pm standard error of the mean of three independent experiments. For statistical analysis, one-way of ANOVA followed by a post-hoc test (Bonferroni's multiple comparisons test) was used. ${ }^{* * *} \mathrm{P}<0.001 \mathrm{vs}$. control (dimethyl sulfoxide-treated cells).

A

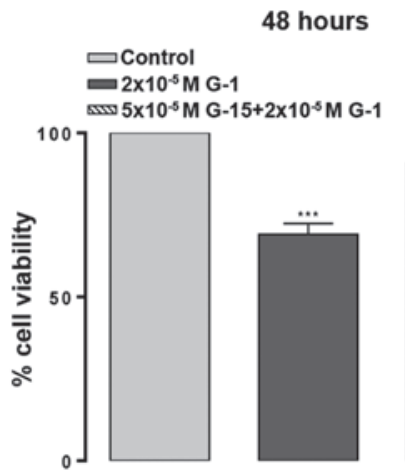

B

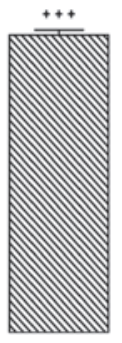

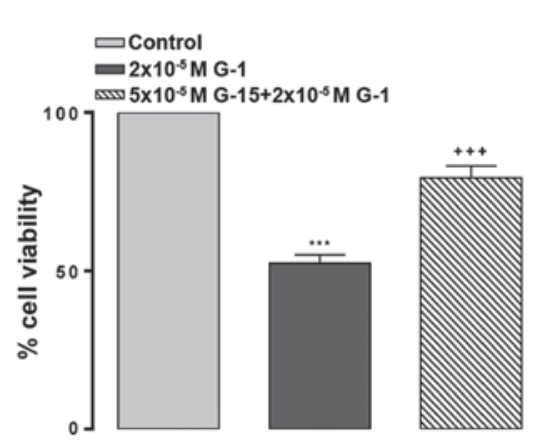

Figure 2. A549 cells were treated with GPER1 antagonist G-15 for 1 h prior to treatment with G-1 for (A) 48 and (B) 72 h. A549 cell viability was determined by MTT assay. Bars represent the mean \pm standard error of the mean. ${ }^{* * *} \mathrm{P}<0.001$ vs. control, ${ }^{+++} \mathrm{P}<0.001$ vs. G-1. control, dimethyl sulfoxide-treated cells.

used as a measure of $\mathrm{NO}$ production. Nitrite concentration was determined using a classic colorimetric Griess reaction. Briefly, equal volumes of samples and Griess reagent (Sigma-Aldrich) were mixed at room temperature. After $5 \mathrm{~min}$, the absorbance was measured at $540 \mathrm{~nm}$ using a spectrophotometer (UV 1201; Shimadzu Scientific Instruments, Inc., Columbia, MD, USA). The concentration of nitrite was determined using a standard curve prepared with sodium nitrite (28).

Data and statistical analysis. Statistical significance was determined by one-way analysis of variance followed by Bonferroni's multiple comparisons test. $\mathrm{P}<0.05$ was considered to indicate statistical significance. All statistical analyses

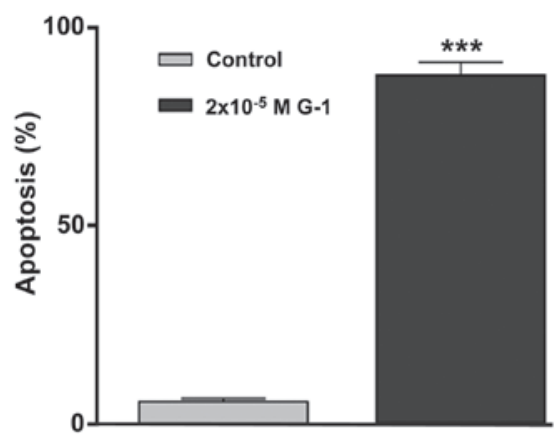

Figure 3. G-1-treated cells (72 h) were double-stained with acridine orange/ethidium bromide and observed by fluorescence microscopy (magnification, $\mathrm{x} 100) .{ }^{* * *} \mathrm{P}<0.001 \mathrm{vs}$. control (Student's $t$-test). Control, dimethyl sulfoxide-treated cells. 

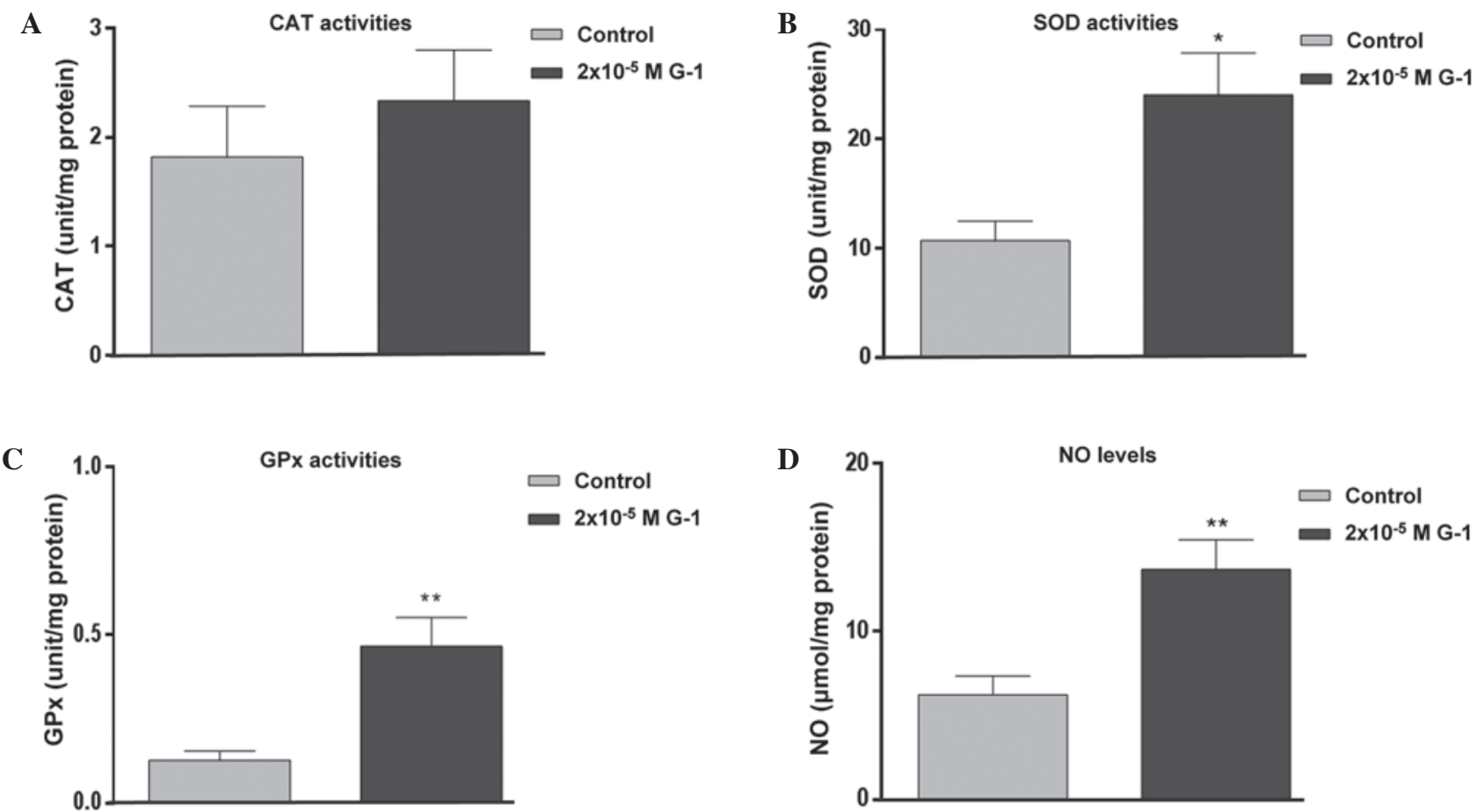

Figure 4. (A) CAT, (B) SOD, and (C) GPx activities and (D) NO levels in G-1-treated A549 cells. "P<0.05, ${ }^{* *} \mathrm{P}<0.01$ vs. control (Student's $t$-test). Control, dimethyl sulfoxide-treated cells; CAT, catalase; SOD, superoxide dismutase; GPx, glutathione peroxidase; NO, nitric oxide.

were performed using GraphPad Prism software version 5.0, (GraphPad Software, Inc., La Jolla, CA, USA).

\section{Results}

G-1 inhibits A549 cell proliferation. Treatment for 48 and $72 \mathrm{~h}$ with 173-estradiol in A549 cells had no significant effect on cell proliferation (Fig. 1). However, treatment with G-1 (10-5 and $10^{-4} \mathrm{M}$ ) for 48 and $72 \mathrm{~h}$ significantly decreased cell proliferation $(\mathrm{P}<0.001$; Fig. 1).

G-15, a selective GPER1 antagonist, blocks G-1-induced suppression of $A 549$ cell proliferation. At $72 \mathrm{~h}$, the $\mathrm{IC}_{50}$ value for G-1 was calculated to be $2 \times 10^{-5} \mathrm{M}$. Treatment with $5 \times 10^{-5} \mathrm{M}$ of the GPER1 antagonist G-15 suppressed the effect on cell proliferation of $2 \times 10^{-5} \mathrm{M} \mathrm{G}-1$ treatment for $48 \mathrm{~h}(\mathrm{P}<0.001$; Fig. 2A) and $72 \mathrm{~h}(\mathrm{P}<0.001$; Fig. 2B).

G-1 induces apoptotic cell death. Treatment of A549 cells with G-1 at a concentration of $2 \times 10^{-5} \mathrm{M}$ revealed a significant increase in apoptosis, consistent with its antiproliferative effect ( $\mathrm{P}<0.001$; Fig. 3).

G-1 increases oxidant levels and antioxidant enzyme activities. G-1 treatment at a concentration of $2 \times 10^{-5} \mathrm{M}$ had no significant effect on CAT activity (Fig. 4A). However, this treatment led to a significant increase in SOD activity $(\mathrm{P}<0.05$; Fig. 4B), GPx activity $(\mathrm{P}<0.01$; Fig. $4 \mathrm{C})$ and $\mathrm{NO}$ level $(\mathrm{P}<0.01$; Fig. 4D).

\section{Discussion}

The present study investigated the antiproliferative and proapoptotic effects of the GPER1 agonist G-1 in lung cancer cells, and attempted to understand how oxidant and antioxidant molecules may mediate this effect. Using two different tetrazolium salt (MTT and WST) assays, G-1 treatment of various concentrations and for different times was revealed to decrease A549 cell proliferation and viability. These two similar and alternative kits were used to determine the $\mathrm{IC}_{50}$ value for G-1. The current results demonstrating the antiproliferative and proapoptotic effects of G-1 on A549 lung cancer cells are similar to those of previous studies, which showed that G-1 suppresses ovarian (KGN), breast cancer (MCF-7, MDA-MB 231) and prostate cancer (PC-3) cell proliferation and induces cell apoptosis (16-18). Furthermore, the receptor-dependent antiproliferative and proapoptotic effects of G-1 were similar to the receptor-dependent effects previously observed in PC-3 prostate and MCF-7 breast cancer cells $(16,17)$. To date, the information established regarding apoptotic signal transduction indicates that certain molecules and enzymes that are responsible for intracellular signaling pathways are also responsible for the signal transduction events during apoptosis (29). For example, calcium ions $\left(\mathrm{Ca}^{2+}\right)$, which are widely used in intracellular signaling, also play a role in apoptosis: An increase in the intracellular concentration of $\mathrm{Ca}^{2+}$ can lead to the induction apoptosis (29). It has been demonstrated that G-1 increases phosphoinositide 3-kinase-mediated calcium mobilization in MCF-7 and SKBR-3 in breast cancer cells (30). Following G-1 treatment, the increase in cytoplasmic $\mathrm{Ca}^{2+}$ ions in A549 cells may induce mRNA expression levels of phosphorylated mitogen-activated protein kinases and proto-oncogene c-jun, which can trigger apoptosis (31).

The present study aimed to investigate whether oxidative and antioxidative enzymes were able to mediate the proapoptotic and antiproliferative effects of G-1. SOD catalyzes the conversion of superoxide molecules into $\mathrm{H}_{2} \mathrm{O}_{2}$ and molecular 
oxygen $\left(\mathrm{O}_{2}\right)$. Then, $\mathrm{H}_{2} \mathrm{O}_{2}$ molecules are converted into water and oxygen by the activity of GPx and CAT enzymes (32). These reactions protect the cells from damage under normal conditions (33). In the present study, an increase in the antioxidant defense system (i.e. SOD and GPx enzyme activities) was observed in A549 cells. $\mathrm{H}_{2} \mathrm{O}_{2}$ accumulation can occur as a result of this increase $(34,35) . \mathrm{H}_{2} \mathrm{O}_{2}$ is a reactive oxygen species, and also an important signaling molecule. Various studies have shown that mitochondrial $\mathrm{H}_{2} \mathrm{O}_{2}$ is a direct trigger of apoptosis (35). The administration of 100 and $150 \mu \mathrm{M}$ resveratrol increased apoptosis rates to maximum values of 50 and $20 \%$, respectively, for the androgen-sensitive $\mathrm{LNCaP}$ cancer line and the androgen-insensitive PC-3 cancer line (36). Therefore, resveratrol may serve as an effective agent in early, mid and late stages of cancer (36). Khan et al (37) demonstrated that resveratrol causes an increase in SOD, CAT, and GPx enzyme activities and apoptosis in PC-3 prostate carcinoma and HepG2 liver carcinoma cells, and that $\mathrm{H}_{2} \mathrm{O}_{2}$ mediates these events. Resveratrol has been demonstrated to inhibit potassium channels via GPER1 in various cell lines, and this inhibition may induce apoptosis (38).

Thus far, the role of NO in tumor biology has not been elucidated; however, it has been hypothesized that NO plays a role in various physiological and pathophysiological processes, including vasodilation, nerve conduction, immune system processes and cancer (39). The results of the present study demonstrated that G-1 treatment significantly increased cell death, and was associated with significantly increased NO levels. NO may be involved in this process in two different ways, primarily by the interaction of NO with superoxides and peroxynitrite, resulting in toxic effects such as DNA damage, protein thiol exchange and inactivation of mitochondrial enzymes in the respiratory chain or citric acid cycle. All of these reactions may be linked to NO-induced apoptosis (39). Furthermore, the secondary cause of the significant increase in NO levels may be associated with nitrite accumulation in the culture medium due to apoptotic cell death.

In conclusion, the present study demonstrated that the GPER agonist G-1 had proapoptotic and antiproliferative effects on A549 NSCLC cells, which may be mediated through oxidative and antioxidative enzymes, including SOD and GPX. A better understanding of GPER1's role in lung cancer will contribute significantly to disease management and prevention. GPER1 may serve as a novel target for lung cancer therapies, and the regulation of GPER1 signaling in cancer treatment may prove beneficial for female and male lung cancer patients. Thus, future studies which investigate the use of GPER1-based therapies involving G-1 and/or its derivatives are required.

\section{Acknowledgements}

This study was supported by a grant from Kahramanmaraş Sütçü İmam University (BAP-2013/1-27M).

\section{References}

1. Lortet TJ, Soerjomataram I, Ferlay J, Rutherford M, Weiderpass $\mathrm{E}$ and Bray F: International trends in lung cancer incidence by histological subtype: Adenocarcinoma stabilizing in men but still increasing in women. Lung Cancer 84: 13-22, 2014.
2. Jemal A, Siegel R, Ward E, Murray T, Xu J, Smigal C and Thun MJ: Cancer statistics, 2006. CA Cancer J Clin 56: 106-130, 2006.

3. Molina JR, Yang P, Cassivi SD, Schild SE and Adjei AA: Non-small cell lung cancer: Epidemiology, risk factors, treatment and survivorship. Mayo Clin Proc 83: 584-594, 2008.

4. Wang T, Nelson RA, Bogardus A and Grannis FW Jr: Five-year lung cancer survival: Which advanced stage nonsmall cell lung cancer patients attain long-term survival? Cancer 116: $1518-1525,2010$.

5. Deroo BJ and Korach KS: Estrogen receptors and human disease. J Clin Invest 6: 561-570, 2006.

6. Donington JS and Colson YL: Sex and gender differences in non-small cell lung cancer. Semin Thorac Cardiovasc Surg 23: 137-145, 2011.

7. Meinhold CL, Berrington de González A, Bowman ED, Brenner AV, Jones RT, Lacey JV Jr, Loffredo CA, Perlmutter D, Schonfeld SJ, Trivers GE and Harris CC: Reproductive and hormonal factors and the risk of nonsmall cell lung cancer. Int $\mathrm{J}$ Cancer 128: 1404-1413, 2011

8. Cheskis BJ, Greger JG, Nagpal S and Freedman LP: Signaling by estrogens. J Cell Physiol 213: 610-617, 2007.

9. Dubey S, Siegfried JM and Traynor AM: Non-small-cell lung cancer and breast carcinoma: Chemotherapy and beyond. Lancet Oncol 7: 416-424, 2006.

10. Pietras RJ, Marquez DC, Chen HW, Tsai E, Weinberg O and Fishbein M: Estrogen and growth factor receptor interactions in human breast and non-small cell lung cancer cells. Steroids 70: 372-381, 2005.

11. Luksha L and Kublickiene K: The role of estrogen receptor subtypes for vascular maintenance. Gynecol Endocrinol 25: 82-95, 2009.

12. Ullrich ND, Krust A, Collins P and MacLeod KT: Genomic deletion of estrogen receptors ERalpha and ERbeta does not alter estrogen-mediated inhibition of Ca2+ influx and contraction in murine cardiomyocytes. Am J Physiol Heart Circ Physiol 294: H2421-H2427, 2008

13. Prossnitz ER, Arterburn JB, Smith HO, Oprea TI, Sklar LA and Hathaway HJ: Estrogen signaling through the transmembrane G protein-coupled receptor GPR30. Annu Rev Physiol 70: 165-190, 2008.

14. Mizukami Y: In vivo functions of GPR30/GPER-1, a membrane receptor for estrogen: From discovery to functions in vivo. Endocr J 57: 101-107, 2010

15. Bologa CG, Revankar CM, Young SM, Edwards BS, Arterburn JB, Kiselyov AS, Parker MA, Tkachenko SE, Savchuck NP, Sklar LA, et al: Virtual and biomolecular screening converge on a selective agonist for GPR30. Nat Chem Biol 2: 207-212, 2006.

16. Chan QK, Lam HM, Ng CF, Lee AY, Chan ES, Ng HK, Ho SM and Lau KM: Activation of GPR30 inhibits the growth of prostate cancer cells through sustained activation of Erk1/2, c-jun/c-fos-dependent upregulation of p21 and induction of G(2) cell-cycle arrest. Cell Death Differ 17: 1511-1523, 2010.

17. Ariazi EA, Brailoiu E, Yerrum S, Shupp HA, Slifker MJ, Cunliffe HE, Black MA, Donato AL, Arterburn JB, Oprea TI, et al: The G Protein-coupled receptor GPR30 inhibits proliferation of estrogen receptor-positive breast cancer cells. Cancer Res 1: 1184-1194, 2010.

18. Wang C, Lv X, Jiang C and Davis JS: The putative G-protein coupled estrogen receptor agonist G-1 suppresses proliferation of ovarian and breast cancer cells in a GPER-independent manner. Am J Transl Res 4: 390-402, 2012.

19. Tong L, Chuang CC, Wu S and Zuo L: Reactive oxygen species in redox cancer therapy. Cancer Lett 367: 18-25, 2015.

20. Kurt AH and Buyukafsar K: Vasoconstriction induced by G1, a G-protein-coupled oestrogen receptorl (GPER-1) agonist, in the isolated perfused rat kidney. Eur J Pharmacol 702: 71-78, 2013.

21. Pektas M, Kurt AH, Un I, Tiftik RN and Buyukafsar K: Effects of $17 \beta$-estradiol and progesterone on the production of adipokines in differentiating 3T3-L1 adipocytes: Role of Rho-kinase. Cytokine 72: 130-134, 2015.

22. Jala VR, Radde BN, Haribabu B and Klinge CM: Enhanced expression of G-protein coupled estrogen receptor (GPER/GPR30) in lung cancer. BMC Cancer 28: 612-624, 2012.

23. Ribble D, Goldstein NB, Norris DA and Shellman YG: A simple technique for quantifying apoptosis in 96-well plates. BMC Biotechnol 5: 12, 2005.

24. Aebi H: Catalase in vitro. Methods Enzymol 105: 121-126, 1984.

25. Lowry OH, Rosebrough NJ, Farr AL and Randall RJ: Protein measurement with the Folin phenol reagent. J Biol Chem 193: 265-275, 1951. 
26. Fridovich I: Superoxide dismutase. Adv Enzymol 41: 35-97, 1974.

27. Levander OA, DeLoach DP, Morris VC and Moser PB: Platelet glutathione peroxidase activity as an index of selenium status in rats. J Nutr 113: 55-63, 1983.

28. Griess JP. Comments on the discussion of the HH. Weselsky and Benedict 'on some azo compounds'. Ber Deutsch Chem Ges 12: 426-428, 1879 (In German).

29. Cohen JJ: Apoptosis: The physiological pathway of cell death. Hosp Pract (Off Ed) 15: 35-43, 1993.

30. Wang C, Lv X, He C, Hua G, Tsai MY and Davis JS: The G-protein-coupled estrogen receptor agonist G-1 suppresses proliferation of ovarian cancer cells by blocking tubulin polymerization. Cell Death Dis 4: e869, 2013.

31. Chan QK, Lam HM, Ng CF, Lee AY, Chan ES, Ng HK, Ho SM and Lau KM: Activation of GPR30 inhibits the growth of prostate cancer cells through sustained activation of Erk $1 / 2$, c-jun/c-fos-dependent upregulation of p21 and induction of G(2) cell-cycle arrest. Cell Death Differ 17: 1511-1523, 2010.

32. Young IS and Woodside JV: Antioxidants in health and disease. J Clin Pathol 54: 176-186, 2001.

33. Khan MA, Tania M, Zhang DZ and Chen HC: Antioxidant enzymes and cancer. Chin J Cancer Res 22: 87-92, 2010.
34. Pallepati P and Averill-Bates DA: Activation of ER stress and apoptosis by hydrogen peroxide in HeLa cells: Protective role of mild heat preconditioning at $40^{\circ} \mathrm{C}$. Biochim Biophys Acta 1813: 1987-1999, 2011.

35. Giorgio M, Migliaccio E, Orsini F, Paolucci D, Moroni M, Contursi C, Pelliccia G, Luzi L, Minucci S, Marcaccio M, et al: Electron transfer between cytochrome c and p66Shc generates reactive oxygen species that trigger mitochondrial apoptosis. Cell 122: 221-233, 2005.

36. Benitez DA, Pozo-Guisado E, Alvarez-Barrientos A, Fernandez-Salguero PM and Castellón EA: Mechanisms involved in resveratrol-induced apoptosis and cell cycle arrest in prostate cancer-derived cell lines. J Androl 28: 282-293, 2007.

37. Khan MA, Chen HC, Wan XX, Tania M, Xu AH, Chen FZ and Zhang DZ: Regulatory effects of resveratrol on antioxidant enzymes: A mechanism of growth inhibition and apoptosis induction in cancer cells. Mol Cells 35: 219-225, 2013.

38. Dong WH, Chen JC, He YL, Xu JJ and Mei YA: Resveratrol inhibits $\mathrm{K}(\mathrm{v}) 2.2$ currents through the estrogen receptor GPR30-mediated PKC pathway. Am J Physiol Cell Physiol 305: 547-557, 2013.

39. Pacher P, Beckman JS and Liaudet L: Nitric oxide and peroxynitrite in health and disease. Physiol Rev 87: 315-424, 2007. 